Home bias in international equity portfolios: a review

Piet Sercu and Rosanne Vanpée

DEPARTMENT OF ACCOUNTANCY, FINANCE AND INSURANCE (AFI) 


\title{
Home Bias in International Equity Portfolios: a Review
}

\author{
Piet Sercu and Rosanne Vanpée*
}

August 8, 2007

\begin{abstract}
This paper reviews the recent literature on equity home bias - the empirical finding that people overinvest in domestic stocks relative to the theoretically optimal investment portfolio. We cover different home bias measures and we illustrate the extent and the evolution of equity home bias both with recent portfolio holdings data and longer time series. Institutional-based and behavior-based explanations for the puzzle are considered and discussed. We conclude that none of the proposed theories can explain the full extent of the bias by itself, thus we argue that international portfolio choice should be explained by a mixture of rational and irrational behavior.
\end{abstract}

*Rosanne Vanpée, the corresponding author (rosanne.vanpee@econ.kuleuven.be) gratefully acknowledges financial support from the Fonds for Wetenschappelijk Onderzoek-Vlaanderen (FWO-Vlaanderen). Both authors are otherwise at KU Leuven, Leuven School of Business and Economics, Naamsestraat 69, B-3000. 


\section{Introduction}

Although international portfolio theory prescribes that optimal portfolios should be well diversified internationally, in practice investors have a clear preference for domestic assets. In the finance literature, this is called the home bias puzzle. Excellent literature reviews on home bias up to the year 2000 can be found in Lewis (1999) and Karolyi and Stulz (2003). In this paper, we cover only the recent findings on international portfolio choice, to avoid too much overlap with the work of Lewis and Karolyi and Stulz. Studies that attempt to resolve the equity home bias puzzle primarily focus on institutional explanations or individual investor behavior. Institutional-based explanations for home bias include hedging possibilities against domestic risks, trading costs and border controls, information asymmetries, and country-level and firmlevel governance. A behavioral-based explanation focuses on investor-specific characteristics such as familiarity, patriotism and overconfidence. We discuss each potential explanation for the equity home bias and argue that no single explanation can capture the full extent of international underdiversification on its own. Home bias is probably caused by a mixture of both institutional and behavioral biases, and therefore it is a very complex task to find a theoretical model that correctly describes actual portfolio choice.

The remainder of the paper is structured as follows. In Section 1, we review the various measures of the equity home bias, we illustrate how severely underdiversified actual equity portfolios are, and we show that the equity home bias has decreased slightly over time. In Section 2, we illustrate the potential benefits of international diversification and compare these benefits with the implicit costs of holding foreign stocks. Section 3 covers the explanations for the equity home bias brought forward in the literature, and the final section concludes.

\section{The equity home bias: facts and figures}

Equity home bias refers to the empirical finding that investors deliberately tilt their portfolios towards domestic assets and thus forego important diversification benefits offered by an internationally well-spread portfolio. It has been shown that home bias is not restricted to an international setting. Even within borders there seems to be a tendency for investors to bias their portfolios towards firms that are situated in their own region. To avoid confusion and to be consistent with the literature, we call the preference for domestic assets "home bias" and the preference for local assets within one country "local bias". In the next subsection, we 
describe how home bias can be measured.

\subsection{How to measure the equity home bias}

The interpretation of and explanation for the equity home bias depends on the characterization of the benchmark weights, i.e. those to which actual holdings can be compared. Following Baele, Pungulescu and Ter Horst (2007), we make a distinction between a "model-based" approach and a "data-based" approach to measure home bias.

In a "model-based" approach, one can use the optimal portfolio weights from an international asset-pricing model as benchmark weights to compare with actual portfolio holdings. The world CAPM assumes that every investor is of the mean-variance type and has the same beliefs about the distribution of real asset returns. All investors face identical investment opportunities and there are no transaction costs or taxes. Inflation is independent of asset returns (or zero) and there is no exchange rate risk. These assumptions result in the well-known relationship:

$$
E\left(r_{j}\right)-r=\beta_{j} *\left[E\left(r_{w}\right)-r\right]
$$

where $E\left(r_{j}\right)$ and $E\left(r_{w}\right)$ denote the expected returns on any asset and the world portfolio respectively, $r$ is the risk-free rate, and $\beta_{j}:=\operatorname{cov}\left(r_{w}, r_{j}\right) / \operatorname{var}\left(r_{w}\right)$. The world CAPM implies that all investors hold the world market portfolio, which is a portfolio where the weight of each asset is equal to its relative share in the world market capitalization. The international asset pricing model (InCAPM) of Sercu (1980) takes exchange rates into account, and equation (1) becomes

$$
E\left(r_{j}\right)-r=\beta_{j} *\left[E\left(r_{w}\right)-r\right]+\sum_{i=1}^{N-1} \delta_{j, s_{i}}\left[E\left(s_{i}+r_{i}\right)-r\right],
$$

where $N$ is the number of countries in the world, $s$ denotes the exchange rate change and $r$ is now the risk-free rate of reference country $N$. In Sercu's model, currency risk can be perfectly hedged with the investor's own risk-free asset, implying that all investors hold the world market portfolio of risky assets, as in the world CAPM. Thus, in either model, the home-bias measure is equal to the difference between the optimal CAPM foreign country weight in the portfolio and observed holdings of foreign equities:

$$
H B_{C A P M}=\text { domestic holdings }-\frac{\text { home capitalization }}{\text { world capitalization }} .
$$


The empirical validity of the world CAPM and the InCAPM is tested by the equations:

$$
\begin{array}{lr}
r_{j}-r=\alpha_{j}+\beta_{j}\left(r_{w}-r\right)+\varepsilon_{j} & \text { (world CAPM }) \\
r_{j}-r=\alpha_{j}+\beta_{j}\left(r_{w}-r\right)+\sum_{i=1}^{N-1}\left(s_{i}+r_{i}-r\right)+\varepsilon_{j} & (\text { InCAPM })
\end{array}
$$

with $r_{j}$ and $r_{w}$ the observed returns on the portfolio $j$ and the world portfolio of equities. If the intercept $\alpha$ is significantly different from zero, the CAPM is empirically invalid. In practice, the empirical validity of the CAPM is very weak and its assumption of perfectly integrated markets is untenable (Ferson and Harvey, 1994). This is even more evident if we evaluate the prediction that all investors should hold the same portfolio.

Alternatively, in a "data-based" approach, benchmark portfolio weights can be calculated from a mean-variance optimization problem with sample estimates of the means and variances of stock returns. The mean-variance framework dates back form Markowitz (1952) and Sharpe (1963). In a setting with $N$ risky assets with expected return $r_{n}(n=1,2, \ldots, N)$, collected in a vector $R$ and a covariance matrix $\Omega$, and a risk free asset with return $r$, investors make a portfolio choice that has a desired expected return $m$ and a variance that is as small as possible:

$$
\begin{aligned}
& \min _{x} x^{\prime} \Omega x \\
& \text { subject to } \quad x^{\prime} R+\left(1-x^{\prime} \underline{1}\right) r=m,
\end{aligned}
$$

where $x$ denotes the $(N \times 1)$ vector of all risky asset weights in the portfolio and $\underline{1}$ is a $(N \times 1)$ vector of ones. The portfolio weights of risky assets are then equal to:

$$
x=\frac{\Omega^{-1} R_{e}}{\underline{1}^{\prime} \Omega^{-1} R_{e}} .
$$

with $R_{e}=R-\underline{1} r$ the vector of expected excess returns of the risky assets, and $x$ is rescaled such that all elements in $x$ sum to unity.

The problem with the data-based approach is that expected returns are unobserved and thus actual returns should be used to calculate the optimal portfolio weights. However, realized returns are bad proxies for expected returns (Merton, 1980). The effect of imprecisely estimated expected returns on the estimated portfolio holdings is worsened by the fact that the optimal portfolio weights are highly sensitive to changes in expected returns. This high sensitivity arises from the fact that the returns of the industrialized countries are highly positively correlated and thus the estimated covariance matrix is close to singular (Jeske, 2001). Therefore, the data-based approach can result in extreme and volatile equity positions. 
Dahlquist, Pinkowitz, Stulz and Williamson (2003) argue that the definition of the equity home bias as the difference between the proportional domestic equity investments and the proportional market capitalization - the benchmark portfolio of the model-based approach is incorrect. This is because the total market capitalization of stocks also contains those assets that are not freely tradable due to, for instance, controlling shareholders who are reluctant to sell their shares. Thus, regular investors cannot hold the world market portfolio; at best, they buy a share in the world portfolio of shares not held by controlling shareholders. Therefore, the world float portfolio (this is the market capitalization-weighted portfolio of freely floated shares) as in La Porta, Lopez-de-Silanes and Shleifer (1999) should be used as a benchmark portfolio to compare with actual portfolio holdings. When using this world float portfolio as a benchmark, Dahlquist et al. show that the home bias is reduced, but does not disappear.

Baele et al. (2007) compare home bias measures based on five different frameworks: (1) the purely model-based international CAPM, (2) the purely data-based mean-variance optimization approach, (3) the Bayesian approach of Pástor (2000) where the investor has some degree of distrust in the asset pricing model, (4) the Multi-Prior technique of Garlappi et al. (2007) which introduces estimation risk in the standard mean-variance model and (5) the combination of the volatility correction model of Garlappi et al. and the Bayesian approach of Pástor. Baele et al. find that the purely model-based approach leads to a severe overestimation of the equity home bias. Using a Bayesian approach that accounts for distrust in the model, the average home bias measure is $22 \%$ lower than the one implied by the model-based approach.

Sercu and Vanpée (2007a) develop a data-based home bias measure that is deducted from mean-variance portfolio theory, notably the difference between the covariance risk of asset $i$ in foreign investor l's portfolio and the covariance risk of asset $i$ in investor $i$ 's portfolio:

$$
\operatorname{cov}\left(r_{i}^{h}, r_{p(l)}^{h}\right)-\operatorname{cov}\left(r_{i}^{h}, r_{p(i)}^{h}\right)
$$

where $r_{i}^{h}$ denotes the hedged equity return of the foreign (host) country $i$, and $r_{p(l)}^{h}$ is the hedged return of the observed portfolio of home country investor $l .^{1}$ One advantage of this home bias measure is that it only relies on the estimation of the covariance matrix of risky assets and on the actual international portfolio holdings. Merton (1980) shows that the variancecovariance matrix of risky assets can be estimated with far more precision than expected

\footnotetext{
${ }^{1}$ The equity return $r_{i}^{h}$, is stock $i$ 's return hedged for exchange rate risk and stock market returns that are not included in the sample. We return to the Sercu-Vanpée model in Section 2.
} 
returns. However, a correct estimation of the covariance matrix remains crucial for the SercuVanpée home bias measure: Sercu and Vanpée (2007b) show empirically that a simple historical covariance matrix can lead to home bias measures for the emerging markets that are incorrect and severely overestimated, notably when the estimates fail to take into account that the Asian crisis is long over, and unlikely to return soon. A far better result is obtained when a Constant Conditional Correlation (CCC) TGARCH-model is used to estimate the covariance matrix, which gives more weight to recent returns and accounts for asymmetries in the feedback mechanism.

In the next subsection, we illustrate the equity home bias with recent data on international portfolio holdings and show the evolution of international diversification over time.

\subsection{The home bias in figures}

To illustrate the intensity of the home bias, Table 1 shows the difference between the proportion of domestic equities in a country's portfolio of stocks and the relative market capitalization of that country at the end of 2005. Data on portfolio holdings are from the Coordinated Portfolio Investment Survey held by the IMF and market capitalizations are from the World Federation of Exchanges. Table 1 shows that all countries hold significantly home-biased equity portfolios. The equity home bias is the lowest in the Netherlands, where only 32 percent of the total equity portfolio is invested in domestic stocks, and the highest in Indonesia, where nearly all equity investments are domestic. In general, the equity home bias is lower in the developed countries and higher in emerging markets. It is interesting to note that the countries with the most volatile stock markets (the emerging markets) are also the ones with their equity portfolios most heavily tilted towards domestic assets. This means that either domestic investors of those countries bear a substantial amount of unrewarded country-specific risk, or international investors are unwilling to cash in an expected return for a risk that, to them, is diversified away. The challenge for academics thus is to explain this behavior.

\subsection{Evolution of the equity home bias over time}

Baele, Pungulescu and Ter Horst (2007) show empirically that the home bias has come down over the years, especially in EU-member states since the European integration. We show in Figure 1 that also for non-EU countries there has been a modest trend towards more diversification. The equity home bias has decreased slightly over the years. 
Figure 1: Home bias over time
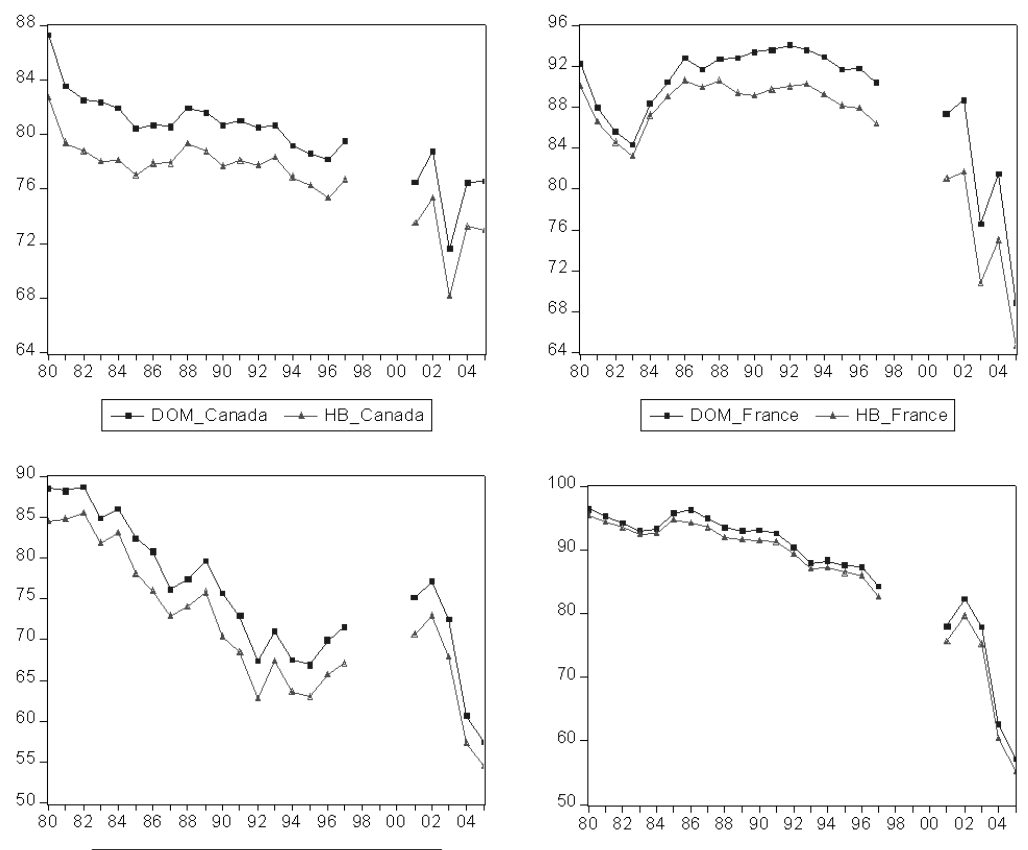

$\rightarrow$ DOM_Germany $\rightarrow$ HB_Germany

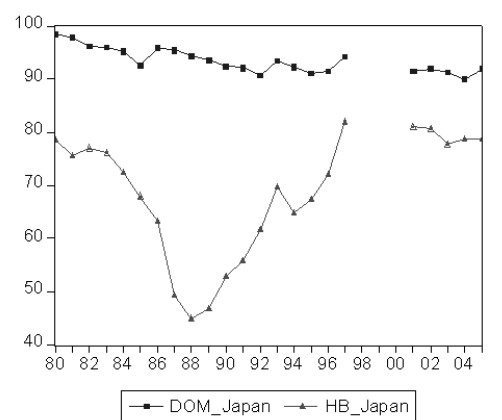

$\rightarrow$ DOM_Italy $\rightarrow$ HB_ttaly
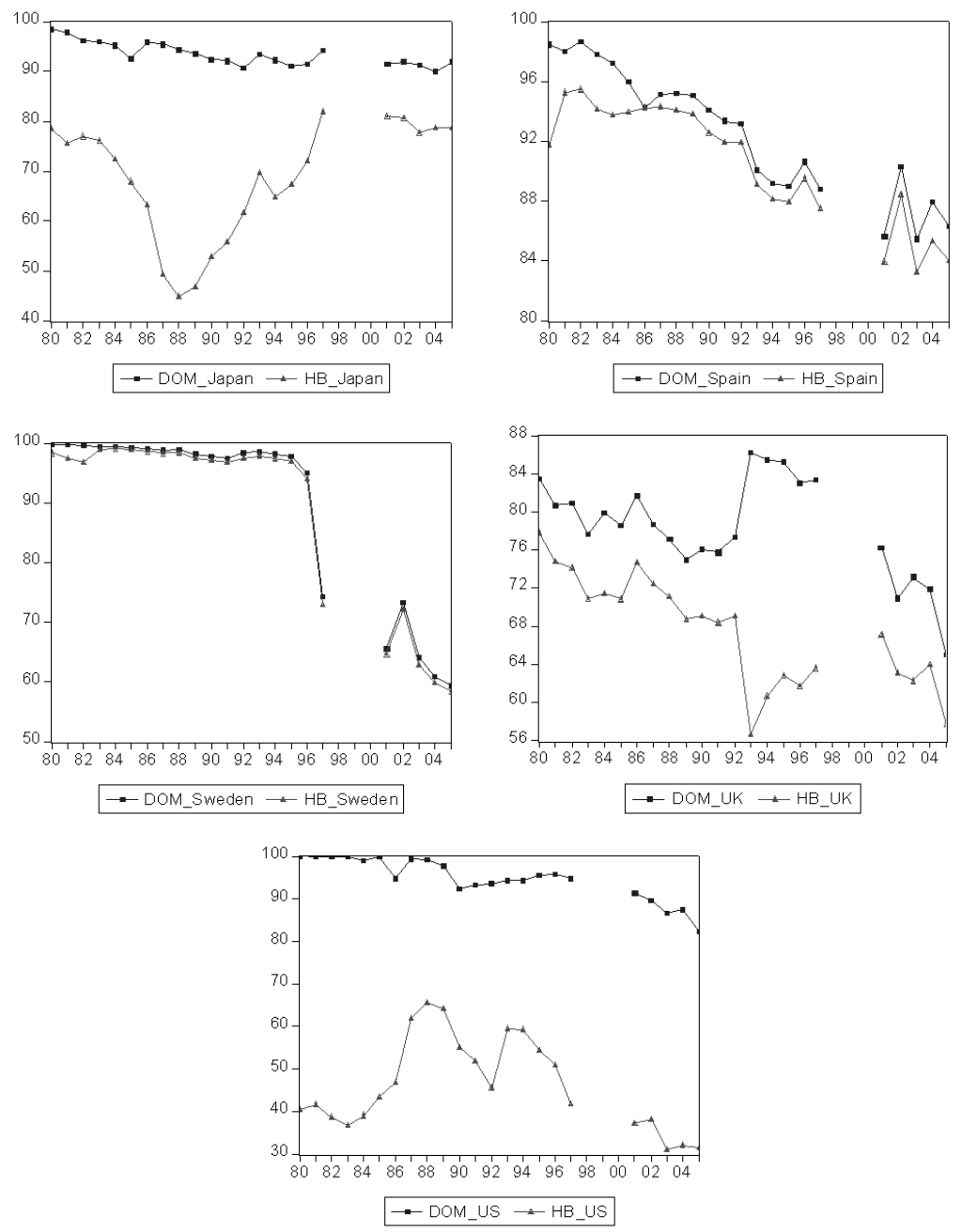
Table 1: Home bias in equity portfolios based on CPIS data, December 2005. Portfolio holdings data are from the CPIS. Market capitalizations are from the World Federation of Exchanges. The home bias in equity portfolios is calculated by subtracting the proportional market capitalization from the proportion of domestic equities in a countries portfolio. All figures are in USD million.

\begin{tabular}{|c|c|c|c|c|c|c|c|}
\hline Country & $\begin{array}{c}\text { Domestic } \\
\text { Market } \\
\text { Capitalization }\end{array}$ & $\begin{array}{c}\text { Foreign } \\
\text { Assets }\end{array}$ & $\begin{array}{c}\text { Foreign } \\
\text { Liabilities }\end{array}$ & $\begin{array}{l}\text { Domestic } \\
\text { Equity } \\
\text { Holdings }\end{array}$ & $\begin{array}{c}\text { \%arket cap } \\
\text { in world } \\
\text { market }\end{array}$ & $\begin{array}{c}\text { \% domestic } \\
\text { in total } \\
\text { equity }\end{array}$ & $\begin{array}{l}\text { HOME } \\
\text { BIAS }\end{array}$ \\
\hline Argentina & 47,590 & 9,558 & 1,971 & 45,619 & 0.1 & 82.7 & 82.6 \\
\hline Australia & 804,015 & 126,418 & 158,336 & 645,679 & 1.9 & 83.6 & 81.7 \\
\hline Austria & 126,309 & 63,566 & 36,647 & 89,662 & 0.3 & 58.5 & 58.2 \\
\hline Belgium & 286,326 & 202,205 & 86,028 & 200,297 & 0.7 & 49.8 & 49.1 \\
\hline Brazil & 474,647 & 2,809 & 99,706 & 374,941 & 1.1 & 99.3 & 98.1 \\
\hline Canada & $1,482,185$ & 363,067 & 296,496 & $1,185,688$ & 3.5 & 76.6 & 73.0 \\
\hline Chile & 136,493 & 23,016 & 5,942 & 130,551 & 0.3 & 85.0 & 84.7 \\
\hline Colombia & 50,501 & 1,009 & 1,186 & 49,315 & 0.1 & 98.0 & 97.9 \\
\hline Czech Republic & 53,798 & 4,386 & 6,549 & 47,249 & 0.1 & 91.5 & 91.4 \\
\hline Denmark & 187,161 & 88,038 & 39,293 & 147,868 & 0.4 & 62.7 & 62.2 \\
\hline Egypt & 79,509 & 898 & 4,513 & 74,996 & 0.2 & 98.8 & 98.6 \\
\hline Finland & 228,266 & 64,471 & 117,041 & 111,225 & 0.5 & 63.3 & 62.8 \\
\hline France & $1,769,569$ & 529,289 & 600,072 & $1,169,497$ & 4.2 & 68.8 & 64.6 \\
\hline Germany & $1,221,106$ & 528,153 & 507,419 & 713,687 & 2.9 & 57.5 & 54.6 \\
\hline Greece & 145,121 & 8,326 & 28,003 & 117,117 & 0.3 & 93.4 & 93.0 \\
\hline Hong Kong & $1,054,999$ & 227,834 & 119,234 & 935,765 & 2.5 & 80.4 & 77.9 \\
\hline Hungary & 32,576 & 1,749 & 13,297 & 19,279 & 0.1 & 91.7 & 91.6 \\
\hline India & $1,069,046$ & 36 & 100,805 & 968,242 & 2.5 & 100.0 & 97.4 \\
\hline Indonesia & 81,428 & 93 & 17,275 & 64,153 & 0.2 & 99.9 & 99.7 \\
\hline Israel & 122,578 & 8,169 & 35,864 & 86,714 & 0.3 & 91.4 & 91.1 \\
\hline Italy & 798,073 & 416,446 & 242,896 & 555,177 & 1.9 & 57.1 & 55.2 \\
\hline Japan & $5,542,716$ & 408,575 & 929,135 & $4,613,580$ & 13.2 & 91.9 & 78.7 \\
\hline Korea & 718,011 & 13,913 & 187,502 & 530,508 & 1.7 & 97.4 & 95.7 \\
\hline Malaysia & 180,518 & 1,550 & 23,240 & 157,278 & 0.4 & 99.0 & 98.6 \\
\hline Mexico & 239,128 & 3,041 & 75,378 & 163,750 & 0.6 & 98.2 & 97.6 \\
\hline Netherlands & 575,843 & 478,427 & 349,158 & 226,685 & 1.4 & 32.1 & 30.8 \\
\hline New Zealand & 40,593 & 21,785 & 8,194 & 32,398 & 0.1 & 59.8 & 59.7 \\
\hline Norway & 190,952 & 125,677 & 54,982 & 135,971 & 0.5 & 52.0 & 51.5 \\
\hline Philippines & 39,818 & 184 & 5,696 & 34,122 & 0.1 & 99.5 & 99.4 \\
\hline Poland & 93,602 & 1,671 & 14,754 & 78,848 & 0.2 & 97.9 & 97.7 \\
\hline Portugal & 75,066 & 15,762 & 19,714 & 55,352 & 0.2 & 77.8 & 77.7 \\
\hline Russia & 527,022 & 336 & 48,128 & 478,894 & 1.3 & 99.9 & 98.7 \\
\hline Singapore & 257,341 & 67,592 & 54,970 & 202,370 & 0.6 & 75.0 & 74.3 \\
\hline South Africa & 549,310 & 60,756 & 58,874 & 490,436 & 1.3 & 89.0 & 87.7 \\
\hline Spain & 959,910 & 122,870 & 185,435 & 774,475 & 2.3 & 86.3 & 84.0 \\
\hline Sweden & 420,953 & 202,216 & 124,792 & 296,161 & 1.0 & 59.4 & 58.4 \\
\hline Switzerland & 935,448 & 357,270 & 400,885 & 534,563 & 2.2 & 59.9 & 57.7 \\
\hline Thailand & 123,885 & 1,217 & 25,746 & 98,139 & 0.3 & 98.8 & 98.5 \\
\hline Turkey & 161,538 & 90 & 26,503 & 135,034 & 0.4 & 99.9 & 99.5 \\
\hline United Kingdom & $3,058,182$ & 992,737 & $1,217,227$ & $1,840,956$ & 7.3 & 65.0 & 57.7 \\
\hline United States & $17,000,805$ & $3,317,705$ & $1,664,493$ & $15,336,311$ & 40.5 & 82.2 & 41.7 \\
\hline Venezuela & 7,316 & 405 & 586 & 6,729 & 0.0 & 94.3 & 94.3 \\
\hline Total & $41,949,250$ & $8,863,315$ & $7,993,970$ & $33,955,281$ & 100.0 & & \\
\hline
\end{tabular}

Figure 1 shows the evolution of the percentage of domestic equities in the total equity portfolio and simultaneously the equity home bias for nine OECD countries. The domestic proportion for Japan up to 1997 is for bonds and shares combined. Portfolio holdings data from 1980 to 1997 are from the OECD, data for 2001 to 2005 are from the IMF. The pattern breaks in the charts after 2001 can be due to the fact that the OECD and the IMF use different data collection methods and reporting standards. Therefore, we concentrate on the longest sample, 
1980-1997, and leave the most recent five years as an illustration. For Canada, Germany, Italy, Spain, Sweden and the United States, we see a trend towards more international diversification, but for France, Japan and the UK, the pattern is not so straightforward. In 1993, the home bias figure of the UK dropped despite of the increased percentage of domestic equity holdings. This is due to the introduction of British Telecom on the London exchange in 1993 which heavily increased the total market capitalization of the UK. During the eighties, Sweden was still subject to severe controls on foreign investments; the figure shows a strong diversification wave in the early nineties as a result of Sweden's deregulation. The strong variation in the home bias figures of Japan is mainly due to the changes in the proportional market capitalization. During the late eighties, the Japanese stock market was booming, increasing Japan's market capitalization to 47 percent of the world market cap in 1988. Moreover, in 1987, Nippon Telegraph \& Telephone was introduced on the Japanese stock exchange, at that time the largest company in the world. In the early nineties, stock prices crashed, bringing Japan's proportional market capitalization back to 11 percent at the end of 1997 . The overall picture of Figure 1 confirms the findings of Baele et al:: although home bias in equity portfolios remains strong, there is a trend towards more international diversification.

In the next section we turn to the costs of international portfolios, or similarly the forgone gains of diversification.

\section{The costs of underdiversification}

The costs of underdiversification can be studied using various approaches. We first discuss the estimated costs resulting from a mean-variance portfolio approach and compare these with the gains from diversification calculated with a consumption-based approach. In a third subsection we report the costs of underdiversification calculated by Goetzmann and Kumar (2004) using individual portfolio holdings data.

\subsection{Diversification costs under a mean-variance approach}

In a mean-variance framework, home bias can result from a difference between domestic and foreign investors in the expected returns and/or in the risks (covariance structure) of the assets in the investment set. Several studies consider models where investors adjust their expected returns of foreign assets downwards to reflect market frictions such as transaction costs, infor- 
mation asymmetries and controls on international capital flows (amongst others Glassman and Riddick, 1994, 2001; Solnik, 1996; French and Poterba, 1991; Cooper and Kaplanis, 1994, 2000; Sercu and Vanpée, 2007a, 2007b). Subtracting the costs of investing in foreign assets from the expected returns of these assets results, ceteris paribus, in home asset bias. We discuss various mean-variance based models to estimate the costs of underdiversification and evaluate each one of them in turn.

Following French and Poterba (1991), Glassman and Riddick (2001) and Jeske (2001) compute implied expected returns by solving the equation:

$$
(\mu-\underline{1} r)=\gamma \Omega x^{a c t}
$$

where $x^{a c t}$ is the vector of actual portfolio shares, $\mu-r \underline{1}$ is the vector expected excess returns, $\gamma$ denotes the coefficient of relative risk aversion (CRRA), and $\Omega$ is the covariance matrix of risky asset returns. The difference between historical returns and the implied returns derived from equation (9) is interpreted as the implicit costs of foreign investments. Returns are deflated by the Consumer Price Index (CPI) to control for inflation risk.

Assuming a level of relative risk aversion of 3, Glassman and Riddick (2001) estimate that over the period 1985 to 1990, implicit investment costs for France, Germany, Japan and the UK should have been in excess of 14 to 19 percent p.a. to explain the observed home bias in equity portfolios. Jeske (2001) calculates the shadow cost of foreign investment for a sample of 11 countries over the period 1991 to 2000, also assuming a level of relative risk aversion of 3. The shadow costs of foreign investments are estimated to be 1.5 percent $p$. $a$. for the U.S., 4.5 percent for Germany, 7.6 percent for Spain and 14.7 percent p.a. for Italy. These cost estimates are far larger than any reasonable measure of explicit or implicit costs since they are nearly as large as the actual returns themselves. The comparison of implied expected returns with historical mean returns to measure the costs of foreign investments is problematic for several reasons. First, realized returns are very bad proxies for expected returns because their estimates are extremely noisy (Merton, 1980; Elton, 1999) and a simple mean historical return does not account for the fact that expected returns can be time-varying. Second, the results are dependent on a postulated and perhaps debatable value for relative risk aversion. Third, the methodology does not account for omitted assets, notably long-term bonds, or non-traded assets, nor for exchange rate risk.

The international portfolio holdings model of Cooper and Kaplanis (1994) is an extension of the international CAPM of Adler and Dumas (1983) and Sercu (1980); it accounts for 
both domestic inflation risk and deadweight costs of foreign investments. In a setting with $N$ countries and $N$ currencies, there are $N$ equity assets, $N-1$ foreign currency bills or notes and a nominally risk free asset. A crucial assumption of the model is that when an investor $l$ holds a foreign asset $i$, he experiences a proportional deadweight loss $C_{i}^{l}$. Under these assumptions, the vector of optimal portfolio holdings of risky assets is equal to:

$$
x^{l}=\frac{1}{\gamma} \Omega^{-1}\left(\mu-r \underline{1}-C^{l}\right)+\left(1-\frac{1}{\gamma}\right) \Omega^{-1} w^{l},
$$

where $x^{l}$ denotes the vector of the proportions of investor l's wealth invested in each risky asset, $C^{l}$ is the vector of deadweight costs, and $w^{l}$ is the vector of covariances of the risky asset returns with investor l's rate of inflation.

Cooper and Kaplanis compute point estimates of the implicit costs of foreign investments, $C$, for a sample of eight developed countries, for different levels of relative risk aversion. Assuming a risk aversion parameter of, for instance, 2.5, they estimate that in 1987 the costs of inward investments were 2.85 percent p.a. for the U.S., 4.28 percent p.a. for France, and 12.65 percent p.a. for Spain. An important advantage of their methodology is that they only need the covariance matrix estimation to calculate the deadweight costs, thus avoiding noisy realized returns as proxies for expected returns. Still, there are some drawbacks: $(i)$ the Cooper-Kaplanis model does not account for non-traded assets or other asset holdings that missing from the sample, (ii) the obtained deadweight cost estimates are just point estimates, thus confidence intervals cannot be computed, (iii) the model does not account for time-varying returns and variances, and $(i v)$ the deadweight-cost estimates are depended on a postulated value for relative risk aversion.

Sercu and Vanpée (2007a, 2007b) generalize the Cooper-Kaplanis model and make use of new portfolio holdings data to solve some of the weaknesses of the original model. First, they use hedged stock returns to account for exchange rates and omitted markets. Second, they premultiply each side of the equation (10) with the covariance matrix of (hedged) stock returns, and, similar to Cooper and Kaplanis, they construct an expression that is independent of expected returns:

$$
\left(y_{i}^{l}-y_{i}^{i}\right)=\frac{1}{\gamma} C_{i}^{l}+\left(1-\frac{1}{\gamma}\right)\left(w_{S_{i} \mid X}^{i}-w_{S_{i} \mid X}^{l}\right),
$$

where $-y_{i}^{l}:=\operatorname{cov}\left(r_{i}^{h}, r_{p(l)}^{h}\right)$ denotes the conditional variance of hedged stock $i$ 's return with the return on the portfolio held by investor $l$, and $w_{S_{i} \mid X}^{l}:=\operatorname{cov}\left(r_{i}^{h}, \Pi^{l}\right)$ is the conditional covariance between the hedged return of stock $i$ with investor $l$ 's inflation rate. Third, Sercu and Vanpée apply a regression technique to the model such that confidence intervals can 
be computed for the average implicit investment costs and the risk aversion parameter can be estimated instead of postulated. Specifically, the deadweight costs of foreign investments are estimated by projecting the costs onto a set of instruments that have been proven to be correlated with home bias. These instruments are organized into six categories, notably information asymmetries, explicit frictions, measures for financial development, measures for economic development, measures for political risk and corporate governance and the skewness in equity returns. Lastly, Sercu and Vanpée (2007b) use the time-varying volatility model of Bekaert and Harvey (1997) to estimate the covariance matrix of risky asset returns. This way the model accounts for time-varying and asymmetric volatilities. Their methodology leads to foreign investment cost estimates for the developed countries that are much lower than the estimates of other authors. For the period 2001 to 2004, implicit inward investment costs are estimated to be 0.01 percent p.a. for the U.S., to 1.55 percent p.a. for Portugal, with relative risk aversion estimated at 1.25. For the emerging markets, the estimated implied costs are higher: from 2.15 percent p.a. for Brazil to 13.88 percent p.a. for Russia. The estimates of foreign investment costs obtained by Sercu and Vanpée are lower and perhaps more plausible than those reported earlier by Cooper and Kaplanis (1994), but still the model is imperfect since it cannot account for non-traded assets as, for instance, human capital.

An alternative method to calculate the costs of underdiversification is proposed by Lau, $\mathrm{Ng}$ and Zhang (2007), who derive the following relationship between the degree of a country's home bias and its cost of capital:

$$
\mu_{l}-r=\gamma \frac{x_{l}^{l}-x_{l}^{*}}{1-x_{l}^{*}}\left(\sigma_{l}^{2}-\sigma_{l, w}\right)+\gamma \sigma_{l, w}
$$

where $x_{l}^{l}$ denotes the proportion of domestic investors' portfolios allocated to domestic equity, $x_{l}^{*}$ is country l's market share in the world market portfolio and $\sigma_{l, w}$ is the covariance of country $l$ 's equity return with the world market portfolio return. The term $\frac{x_{l}^{l}-x_{l}^{*}}{1-x_{l}^{*}}$ measures the degree of home bias and can also be interpreted as the degree of market integration. The model implies that the degree of the home bias will induce a larger cost of capital if $\sigma_{l}^{2}>\sigma_{l, w}$. Empirical evidence shows that this is generally the case (for instance Stulz, 1999 and Lau, $\mathrm{Ng}$ and Zhang, 2007). Lau, Ng and Zhang show that equation (12) can be easily extended to incorporate implicit investment costs as in Cooper and Kaplanis (1994). To estimate the cost of capital, $\mu_{l}-r$, Lau et al. consider three different approaches. First, they calculate the implied cost of capital using a price-to-earnings ratio divided by the earnings growth rate (PEG ratio 
model). ${ }^{2}$ Second, they consider the realized return as an estimate of the expected return; and third, they calculate the the expected dividend yield as a measure of the cost of capital. Their results show that countries that are more strongly home biased have significantly greater costs of capital, even when ownership concentration, foreign investment costs and other countryspecific variables are taken into account. If, for instance, U.S. investors held the world market portfolio, their country's cost of capital would drop with just 0.12 percent, while for Polish investors, the reduction in cost of capital would amount to 1.3 percent. Although these results are appealing, one should keep in mind that they are still fully dependent on an estimate for the expected return. Implied expected returns are better proxies for expected returns than realized returns, but still imperfect (Pastor, Sinha and Swaminathan, 2006). Also the model only considers equity holdings, thus fully ignoring other traded and non-traded asset, exchange rates and inflation rates.

Errunza, Hogan and Hung (1999) show empirically that the estimated costs from underdiversification as calculated from a traditional mean-variance approach are overstated. They find that U.S. investors can mimic foreign market indices and achieve a portfolio that is internationally mean-variance efficient by using domestically traded multinationals, closed-end country funds and American Depository Receipts. The difference between the gains from a home-made diversified portfolio and a portfolio composed of shares trading abroad are statistically and economically insignificant. However, they also find that although the average gains from foreign asset-based diversification are insignificant, there are periods when international markets provide a meaningful diversification that can not be replicated at home. The study of Errunza et al. is carried out from the viewpoint of the U.S. investors. Investors from other countries, especially emerging markets, probably have less opportunities to compose an internationally mean-variance efficient portfolio using domestically traded assets.

We now turn to the costs of international underdiversification resulting from a consumptionbased approach.

\footnotetext{
${ }^{2}$ The PEG ratio model is developed by Easton (2004) and states that the market price of a firm's stock at time $t, p_{t}$ can be determined as $p_{t}=\frac{\left(\hat{x}_{t+2}+r_{P E G} * \hat{d}_{t+1}-\hat{x}_{t+1}\right)}{r_{P E G}^{2}}$, where $\hat{x}_{t+\tau}$ represents the expected future earnings per share for period $(t+\tau-1, t+\tau), \hat{d}_{t+\tau}$ denotes the expected future net dividends per share for period $(t+\tau-1, t+\tau)$ and $r_{P E G}$ is the implied cost of capital.
} 


\subsection{Diversification costs under a consumption-based approach}

As an alternative to the mean-variance portfolio theory approach, the implied costs of underdiversification can be calculated using a consumption-based approach that takes a production process as exogenously given and determines how optimal risk-sharing would affect the investor's consumption path. Early references that compute the welfare gains from international risk-sharing under a consumption based framework are amongst others Cole and Obstfeld (1991), van Wincoop (1994) and Tesar (1993). Welfare gains are usually reported as the permanent percentage increase in expected consumption that leads to an equivalent increase in welfare. The reported results vary wildly depending on $(i)$ the implicit risk-free rate, $(i i)$ the risk-adjusted growth rate, (iii) the rate of relative risk aversion and (iv) endowment uncertainty (van Wincoop, 1999).

We illustrate the consumption-based methodology using the work of Lewis $(1996,2000)$. Calculating the welfare gains from diversification under a consumption-based approach requires the specification of a utility function. A commonly used utility function is the Epstein-Zin-Weil utility function: ${ }^{3}$

$$
U_{t}=\left\{c_{t}^{1-\theta}+\beta\left[E_{t}\left(U_{t+1}^{1-\gamma}\right)\right]^{(1-\theta) /(1-\gamma)}\right\}^{\frac{1}{1-\theta}},
$$

where $\theta$ is the inverse of the intertemporal elasticity of substitution in consumption. In a world with $N$ closed economies (autarky), let $p_{t}^{j}$ denote country $j$ 's stock price and $x_{t}^{j}$ represents the proportion of stocks held by the representative investor that pay out the per capita endowment of country $j, e_{t}^{j}$. The wealth of country $j$ 's investor at time $t$ is thus $w_{t}^{j}=x_{t}^{j} p_{t}^{j}$, and $s_{t}$ is the state of the economy at time $t$. The representative agent maximizes equation (13), given his budget constraint. Specifically, the optimization problem is:

$$
V\left(w_{t}^{j}, s_{t}\right)=\max _{c_{t}^{j}, x_{t}^{j}}\left[\left(c_{t}^{j}\right)^{(1-\theta)}+\beta E_{t}\left(V\left(w_{t+1}^{j}, s_{t+1}\right)^{1-\gamma}\right)^{(1-\theta) /(1-\gamma)}\right]^{\frac{1}{1-\theta}}
$$

subject to

$$
c_{t+1}^{j}+x_{t+1}^{j} p_{t+1}^{j}=\left(p_{t+1}^{j}+e_{t+1}^{j}\right) x_{t}^{j} .
$$

The first order condition for this maximization problem, and the assumption of a log-normal

\footnotetext{
${ }^{3}$ In Epstein-Zin-Weil utility function, developed by Epstein and Zin (1989) and Weil (1990), the parameter of relative risk aversion, $\gamma$, is different from the inverse of the elasticity of intertemporal substitution in consumption, $1 / \theta$, while for CRRA utility functions $\gamma=1 / \theta$.
} 
distribution for the endowments, leads to following expression for the stock price:

$$
p_{t}^{j}=e_{t}^{j}\left\{\beta M_{j}^{(1-\theta)} /\left(1-\beta M_{j}^{(1-\theta)}\right)\right\},
$$

where $M_{j}=\exp \left(\mu_{j}-\frac{1}{2} \gamma \sigma_{j}^{2}\right)$ is the exponential of the risk-adjusted growth rate and $\left(\mu_{j}-\frac{1}{2} \gamma \sigma_{j}^{2}\right)$ is the certainty equivalent consumption growth path. In equilibrium, $x_{t}^{j}=1$ so that each investor holds one share of the endowment of per capita output.

If, in contrast to autarky, financial markets are open, investors of country $j$ can hold $x^{i, j}$ shares in stocks of country $i$ endowments. The budget constraint in (15) can be written as:

$$
c_{t}^{j}+\sum_{i=1}^{N} x_{t}^{i, j} p_{t}^{i} \leq \sum_{i=1}^{N} x_{t-1}^{i, j}\left(e_{t}^{i}+p_{t}^{i}\right) .
$$

Lewis $(1996,2000)$ shows that the maximization problem can also be written in terms of a world mutual fund paying out the world per capita endowment, $\underline{e}_{t}$. Shares of the mutual fund held by country $j$ are defined as $\underline{x}_{t}^{j}$ and its price at time $t$ is $\underline{p}_{t}$. The price of the world mutual fund, $\underline{p}_{t}$ and country $j$ 's stock price, $\underline{p}_{t}^{j}$ can expressed as:

$$
\begin{aligned}
\underline{p}_{t} & =\underline{e}_{t}\left\{\beta \frac{\underline{M}^{(1-\theta)}}{1-\beta \underline{M}^{(1-\theta)}}\right\}, \\
\underline{p}_{t}^{j} & =e_{t}^{j}\left\{\beta \frac{\underline{M}^{-\theta} H_{j}}{1-\beta \underline{M}^{-\theta} H_{j}}\right\},
\end{aligned}
$$

where $\underline{M}=\exp \left(\underline{\mu}_{j}-\frac{1}{2} \gamma \underline{\sigma}_{j}^{2}\right)$ is the exponential of the risk-adjusted growth rate of the world endowment, and $H_{j}=\exp \left(\mu_{j}+\frac{1}{2} \gamma \underline{\sigma}^{2}-\gamma \underline{\sigma}_{j}\right)$, with $\underline{\sigma}_{j}$ the covariance between country $j$ 's endowment growth and the world endowment growth. A country's stock price will increase with its mean growth rate, $\mu_{j}$, and decrease with its covariance with the world endowment, $\underline{\sigma}_{j}$, ceteris paribus.

Recall that the welfare gain from international diversification is defined as the percentage of permanent consumption that must be taken away from an individual to make him indifferent between risk-sharing or not. If $C_{0}^{j}$ is the permanent consumption at time 0 for country $j$, and $C_{0}^{j *}$ is its permanent consumption under optimal risk-sharing, the welfare gain $\delta^{j}$ can be derived from following relationship:

$$
E_{0} U\left\{C_{0}^{j}\right\}=E_{0} U\left\{\left(1-\delta^{j}\right) C_{0}^{j *}\right\} \equiv E_{0} U\left\{\left(1-\delta^{j}\right)\left(\underline{p}_{0}^{1} / \underline{p}_{0}\right) \underline{C}_{0}\right\},
$$

where $\underline{C}_{0}$ is the stream of world per capita endowments. Using the expressions for the stock prices $\underline{p}^{j}$ and $\underline{p}$, the welfare gain can be calculated as:

$$
\begin{aligned}
\delta^{j} & =1-\left(e_{0}^{j} \underline{p}_{0} / \underline{e}_{0} \underline{q}_{0}^{j}\right) E_{0}\left\{U\left(\underline{C}_{0}\right) / U\left(C_{0}^{j}\right)\right\}^{\frac{1}{(1-\theta)}} \\
& =1-\frac{e_{0}^{j} \underline{p}_{0}}{\underline{e}_{0} \underline{p}_{0}^{j}} \frac{\left(1-\beta \exp \left[(1-\theta)\left(\underline{\mu}-1 / 2 \gamma \underline{\sigma}^{2}\right)\right]\right)}{\left(1-\beta \exp \left[(1-\theta)\left(\mu_{j}-1 / 2 \gamma \sigma_{j}^{2}\right)\right]\right)} .
\end{aligned}
$$


Thus, the welfare gain for international diversification depends on the utility under autarky relative to the optimal world portfolio, and on the ratio of the value of domestic equity to world equity.

Using data from 1969 to 1993, Lewis (2000) calculates the gains from international diversification for a U.S. investor and compares the mean-variance portfolio approach with the consumption-based approach. She first calculates the efficient frontier - a combination of foreign and domestic stocks that results in a portfolio providing the highest expected return for any given variance of the return - and then calculates the gains from moving from the utility of a portfolio of 100 percent U.S. stocks to the utility of the portfolio at the efficient frontier. Using a mean-variance equity based approach and fixing the parameter of relative risk aversion at 2, Lewis estimates that the gains from international diversification are in the range of 10 percent of current wealth to 28.8 percent of current wealth (depending on the level of intertemporal elasticity of substitution in consumption). For higher levels of relative risk aversion, welfare gains are even higher. Lewis compares these estimated welfare gains with the gains from diversification estimated from a consumption-based model. The gains for U.S. investors resulting from moving from autarky to an open economy, assuming again that relative risk aversion is equal to 2 , are estimated in the range of 0.04 percent to 0.25 percent of total current consumption. Lewis reasons that the explanation for the difference in the estimated costs of underdiversification resulting from an equity-based mean-variance approach and a consumption-based approach lies in the high variability of stock returns compared to the low variability in consumption growth rates. The gains from international diversification derive from the benefits of reducing the variability of marginal utility over time. In the equitybased approach, marginal utility is assumed to depend on stock returns (which are implicitly assumed to drive consumption, but this link is ignored), while in the consumption-based approach, marginal utility is estimated from consumption.

An important weakness of the consumption-based asset pricing model is that it works poorly in practice, even worse that the CAPM (Campbell and Cochrane, 2000; Gordon and Samson, 2002). Cochrane (1996) compares the mean excess returns of 10 CRSP size portfolios with the predictions of the consumption-based model and concludes that the consumption-based model does not do very well: the pricing error (actual expected return - predicted expected return) for each portfolio is of the same order of magnitude as the spread in expected returns across the portfolio. Another problem with the consumption-based model is that it is not only weak in fitting the data, but it also leads to levels for risk aversion that are too high to be plausible. 
For example, to obtain the best fit for the data, Cochrane (1996) had to impose a risk aversion parameter of 241. The underlying explanation may have to do with the fact that, even in the U.S., consumers' spending is not closely tied to the stock market. Many do not hold stocks, others still derive most of their income from other sources, and even pure rentiers may be less sensitive to prices than theory predicts.

In the next subsection, we consider the costs from underdiversification derived from data on individual portfolio holdings directly instead of from a theoretical model.

\subsection{Diversification costs from individual portfolio holdings}

Goetzmann and Kumar (2004), using a large sample of individual portfolio holdings during the period 1991-1996, calculate the costs of underdiversification by dividing portfolios into groups based on the degree of diversification. Using CAPM-tests and four-factor alphas, they find that the least diversified group of investors earn 2.4 percent lower annual returns than the most diversified group of investors. This performance differential is not due to differences in turnover or transactions costs. Goetzmann and Kumar show that the degree of diversification is related to specific investor characteristics: the economic costs of underdiversification are higher for older investors and investors who trade infrequently. Within these two groups, the risk-adjusted performance differentials between the least diversified and the most diversified investors are 3.60 percent and 3.12 percent, respectively.

Overall, there seems to be a consensus that the gains from international diversification can be substantial. Therefore, the observed preference for domestic equity is even more puzzling. In the next section we consider the various explanations that have been brought forward for the observed home-biased portfolios.

\section{Explanations for the equity home bias}

The list of potential explanations for the equity home bias is extensive. We distinguish between five theories: $(i)$ hedging domestic risk, (ii) implicit and explicit costs of foreign investments, (iii) information asymmetries, ( $i v)$ corporate governance and transparency, and $(v)$ behavioral biases. 


\subsection{Hedging domestic risks}

A first potential explanation for the home bias in equity portfolios is that domestic assets serve as a better hedge for risks that are home-country specific, e.g. inflation risk and domestic consumption risk, since investments in domestic assets are likely to follow the performance of the domestic market in general. We discuss four home-country specific risks in turn: inflation risk, real exchange rate risk, domestic consumption risk, and the risk from non-tradable wealth components such as human capital and non-financial income.

If purchasing price parity (PPP) does not hold, real returns on equity are different for domestic and foreign investors. ${ }^{4}$ With uncertainty about future inflation rates, investors in different countries are induced to hold portfolios that differ by a component designed to hedge inflation risk (Adler and Dumas, 1983). It is only possible to hedge inflation risk with domestic stocks if the domestic stock returns and inflation rates are positively correlated. Empirical evidence for a positive correlation between stock returns and inflation rates is weak (Adler and Dumas, 1983; Cooper and Kaplanis, 1997; Sercu and Vanpée, 2007a), indicating that hedging inflation risk cannot explain the observed home bias.

Deviations from PPP do not only create inflation risk, they also result in real exchange rate risk. Fidora, Fratzscher and Thimann (2007) focus on the role of real exchange rate volatility as a key determinant of international portfolio allocation decisions. An interesting insight of their study is that it does not focus solely on stock holdings, but provides a link between the home bias in the stock and in the bond markets. Their model implies that real exchange rate volatility induces a higher home bias for assets with lower local currency return volatility, i.e. a higher home bias for bonds than for equities. Fidora et al. find that for 40 home countries and up to 120 destination countries, real exchange rate volatility explains 20 to 30 percent of the cross-country variation in equity home biases and even a larger part of the variation in bond home biases.

Chue (2007) proposes an Euler equation to measure the extent to which foreign securities can serve as a better hedge against domestic consumption risks, relative to domestic assets.

\footnotetext{
${ }^{4}$ Empirically, real exchange rates are long-memory processes with only a weak reversion to the mean (Froot and Rogoff, 1995).
} 
He shows theoretically that the equation

$$
E\left[\frac{\delta U^{\prime}\left(C_{t+1}\right)}{U^{\prime}\left(C_{t}\right)}\left(r_{f, t+1}-r_{d, t+1}\right)\right]=0
$$

with $r_{f}$ the gross return of foreign stocks and $r_{d}$ the gross return on domestic stocks, should hold if an investor's relative allocation between domestic and foreign securities is optimal, and $E\left(r_{d}\right)=E\left(r_{f}\right)$. This is because

$$
E\left[\frac{\delta U^{\prime}\left(C_{t+1}\right)}{U^{\prime}\left(C_{t}\right)}\left(r_{f, t+1}-r_{d, t+1}\right)\right] \approx \operatorname{cov}\left(\frac{\delta U^{\prime}\left(C_{t+1}\right)}{U^{\prime}\left(C_{t}\right)}, r_{f, t+1}\right)-\operatorname{cov}\left(\frac{\delta U^{\prime}\left(C_{t+1}\right)}{U^{\prime}\left(C_{t}\right)}, r_{d, t+1}\right),
$$

if $E\left[r_{f, t+1}\right] \approx E\left[r_{d, t+1}\right]$. The right-hand side of equation (23) measures the extent to which foreign securities are a better hedge against domestic consumption risks than domestic securities. Thus, it is optimal for a domestic investor to hold relatively more foreign securities when

$$
E\left[\frac{\delta U^{\prime}\left(C_{t+1}\right)}{U^{\prime}\left(C_{t}\right)}\left(r_{f, t+1}-r_{d, t+1}\right)\right]>0 .
$$

Chue finds that even though foreign equities can help diversify away domestic stock market risks, their ability in hedging domestic consumption risks is much weaker. Based on the Euler equation approach, there is only weak evidence that the existing degree of equity home bias for U.S. investors is suboptimal. Thus, Chue's work provides no evidence that hedging domestic consumption risk can explain the observed home bias in equity portfolios.

Investors may also hold more domestic assets to offset the risk of non-tradable wealth such as non-financial income or human capital. If investors buy domestic stocks to hedge nonfinancial income risks, we expect a positive correlation between non-financial and financial income to be associated with a reduction of the investment in risky assets and a negative correlation to be associated with an increase in it. Massa and Simonov (2006) show that the non-financial income is uncorrelated with the market portfolio of financial assets, but actual investors' portfolios (which differ from the market portfolio) are more positively correlated to non-financial income than the market portfolio is. Thus, investors deliberately decide not to hedge non-financial income risks, by tilting their portfolios in such a way that they are positively correlated with non-financial income. They conclude that hedging the risk of nonfinancial income fails to explain the equity home bias. But their findings are controversial: Baxter and Jermann (1997) find not a zero correlation, but a positive link between the returns on human capital and domestic equities, which implies that investors should reduce their holdings in domestic equities in order to hedge their human capital risks. Bottazzi, Pesenti and van Wincoop (1996) and more recently Julliard (2003), in contrast, find a negative correlation 
between human capital returns and domestic equities, suggesting a possible explanatory power of hedging human capital risks for the home bias puzzle.

None of the studies that consider hedging as an explanation for the home bias in equities can provide truly convincing results. Hedging domestic risks cannot qualify as the single explanation for international underdiversification. We turn to the next possible explanation: investing in foreign equities generates costs that are higher than the possible gains from diversification.

\subsection{Costs and barriers for foreign investments}

Most of the early literature that tries to explain home bias focuses on transaction costs and the role of barriers to international investments. Black (1974) develops a model with taxes on net foreign investments that leads to a tilt in portfolios towards domestic assets. These taxes are broadly defined and can represent for instance the risk of expropriation of foreign holdings, direct controls on capital in- or outflows, reserve requirements on bank deposits and restrictions on the fraction of a company that can be held by foreigners. Other early studies on the effect of costs and barriers to foreign investments on international portfolio holdings are amongst others Stulz (1981) and Errunza and Losq (1985). At that time, it was not unrealistic to assume that explicit barriers cause home-biased portfolios. For many investors, investing in foreign securities was almost impossible because their country forbade them to do so, or made it difficult or impossible for them to obtain foreign currency. Since the early nineties, nearly all countries have liberalized their financial markets, at least to a certain extent. These days, all developed markets and a number of emerging markets are open to foreign investors. In other words, equity home bias, which is highly persistent and still prevalent, cannot be explained by international capital controls.

Another explicit market friction brought forward as an explanation for the home bias are transaction costs. Martin and Rey (2004) develop a two-country model with incomplete asset markets in which the demand for foreign assets decreases with transaction costs in a non-linear way. Those transaction costs can include banking commissions and variable fees, exchange rate transaction costs and information gathering costs. Martin and Rey show theoretically that a severe equity home bias can result from only small transaction costs. Moreover, a size effect comes up due to the presence of these transaction costs and the imperfect substitutability of financial assets: shares from a large country trade at higher prices and have lower expected returns than those from a small country. 
Although the theoretical model of Martin and Rey (2004) leads to appealing conclusions, empirically, transaction costs in the narrow sense cannot be a reasonable explanation for the home bias. If trading in foreign assets is more expensive, one would expect a smaller amount of transactions in foreign assets than in domestic assets. However, Tesar and Werner (1995) find that the turnover rate on foreign equity is far higher than on domestic equity. Warnock (2001) reexamines this finding, and concludes that foreign turnover rates are similar to domestic turnover rates, but transaction costs still fail as an explanation for home bias. Thus, direct costs do not offer a complete or even a major explanation for the home bias. We turn to the third potential explanation, information asymmetries between foreign and domestic investors.

\subsection{Information asymmetries}

A very popular potential explanation for home bias is that the preference for domestic assets is driven by information asymmetries between domestic and foreign investors. Indeed, if there is differential information, risk-averse investors prefer the stocks on which they easily have better information - these are typically the domestic stocks - because they perceive them as less risky.

Brennan, Cao, Strong and Xu (2005) develop a noisy expectations model where investors receive public and private information signals, with the private signal being less precise for foreign investors. They confirm the results from earlier work (Brennan and Cao, 1997) who show empirically that foreign purchases of U.S. investors are positively correlated with the lagged foreign market returns. This is consistent with U.S. investors being at an information disadvantage relative to foreign investors. Additionally, Brennan et al. (2005) show that there is a link between information disadvantages and the expectations (degree of bullishness) about a market. Foreign investors tend to become more bullish about a certain market following a positive return on that market.

Many studies examine the link between information asymmetries and international portfolio choices by regression. Actual portfolio holdings (or, often, differences between actual portfolio holdings and optimal portfolio holdings following an international asset pricing model) are regressed directly on variables that proxy for information asymmetries such as regional and cultural factors (amongst others Chan, Covrig and Ng, 2005; Berkel, 2004; Lane and MilesiFerretti, 2004, 2005; Faruquee, Lee and Yan, 2004). We briefly discuss their main findings.

The proximity of the foreign market is a dominant factor to capture the effects of informa- 
tion asymmetries in portfolio choice problems. Portes and Rey (2005) focus on international equity flows and find that the physical distance between two countries has all the symptoms of being a proxy for information asymmetries. The role of distance in financial decisions is not restricted to international equity or bond investments. Coval and Moskowitz (1999) study the behavior of mutual fund managers in the U.S. who prefer to invest in nearby firms, illustrating a local bias. In a study on Finnish investors, Grinblatt and Keloharju (2001) show that distance and sharing a common language or culture are important factors in portfolio choices. Grote and Umber (2006) show that the local bias also exists in U.S. merger and acquisition decisions. The idea of an information advantage for investors who are physically close to the investment opportunity is enforced by the fact that those investors seem to obtain higher returns than investors located further away. Coval and Moskowitz (2001) find evidence that fund managers who display a stronger local bias achieve higher risk-adjusted returns, while in the same line, Grote and Umber (2006) show that the most successful M\&A deals are the ones that display a stronger local bias. Apparently, being in close proximity to a firm means that investors do have access to more or more accurate information about the firm.

Cultural differences such as speaking a different language or having a different religion can also affect international portfolio choices: information costs occur under the form of translations and adaptation to different cultural or religious habits (Grinblatt and Keloharju, 2001). Several studies show that there is also a size-bias. Faruquee et al. (2004), Chan et al. (2005) and Sercu and Vanpée (2007a), show that (log) GDP or the number of publicly listed companies significantly influences international portfolio holdings. This can be explained by the fact that information on large economies and stock markets is more universally widespread than information on small markets. Sarkissian and Schill (2004) show that apart from geographical and cultural proximity, also industrial (economic) proximity plays an important role: overseas listing decisions of firms reflect investment decisions of investors, since cross-listing activity of firms is more common in markets that are geographically, culturally and industrially proximate. Similarly, Coval and Moskowitz (1999) suggest that "economic distance" as measured by, for instance, air fares or phone rates data, may be a good proxy for information asymmetries between domestic and foreign investors.

There are some difficulties with the assumption of asymmetric information as an explanation for home bias. If investors have better or more information on domestic assets, they not only face a lower variance of domestic equity returns, but also their expected returns should often differ from those of foreign investors. This difference in expected returns depends on 
whether domestic investors observe a signal indicating high or low returns on domestic stocks. Thus, at least in some episodes, informed investors would have to hold fewer domestic stocks than foreigners do, notably if the information indicates a sufficiently low expected return. However, this investment behavior is in contract to actual portfolio holdings, which indicate a continued home bias over decades in all countries (Jeske, 2001).

A second problem with the information-based explanation of home bias is the existence of many index vehicles through which the information disadvantage relative to foreign investors can be largely avoided. Errunza et al. (1999) show empirically that the benefits from an internationally diversified portfolio can be obtained by combining domestically traded multinationals, ADRs and closed-end country funds in the portfolio. Similarly, Brealey, Cooper and Kaplanis (1999) argue that institutional investors can hold country index funds or index futures combined with cash that deliver a return that avoids many of the institutional disadvantages associated with holding individual foreign equities. The question therefore remains why investors do not exploit these opportunities.

Another prediction of the information-asymmetry theory is that, if domestic investors are at an information advantage relative to foreign investors, they should realize higher returns on their equity investments than foreigners. It turns out that the empirical evidence on the performance of foreign versus domestic investors is mixed. For example, Hau (2001) using German data, Dvorak (2005) using Indonesian data, and Choe, Kho and Stulz (2005) using Korean data, find that domestic investors realize higher profits than foreign investors. They therefore conclude that foreigners have an information disadvantage relative to domestic investors. In contrast, Grinblatt and Keloharju (2000) using Finnish data and Huang and Shiu (2006) using data on equity investments in Taiwan, find that foreign investors - often professionally managed funds or investment banking houses - outperform domestic investors. Although there seems to be no real consensus on whether domestic investors outperform foreign investors, the empirical evidence of superior performance by domestic investors is more convincing. The studies that find that foreign investors achieve higher returns recognize that this is the case because foreign investors are mainly professionals who are more experienced and are professionally closer to the market than (domestic) households.

Another criticism on information asymmetries as an explanation for home bias is that it makes the implausible assumption of information immobility, while asymmetric information should disappear when information is tradable. Van Nieuwerburg and Veldkamp (2007) refute this criticism by showing theoretically that a tiny information advantage is sufficient to create 
significantly home-biased portfolios if investors are restricted in the amount of information they can learn about. Their reasoning is as follows. A small information advantage makes local assets less risky relative to foreign assets. Therefore, the investor will probably hold slightly more local assets than a foreign investor would. But, as the investor decides to hold more of the asset, it becomes more valuable to learn about since there are increasing returns to specializing in learning about one asset. Thus, the investor chooses to learn more and hold more of the asset, until his capacity to learn is exhausted. The initial small information advantage is magnified and information immobility persists because investors capitalize on what they already know: by specializing what they have a comparative advantage in, investors increase their information asymmetry.

We now turn to the fourth explanation for equity home bias, notably cross-country differences in corporate governance and transparency.

\subsection{Corporate governance and transparency}

Recent studies have suggested that corporate governance and transparency on the firm-level and political risk on the country-level can also be a driver for equity home bias. There is a strong link between transparency and information asymmetries. Pagano et al. (2001) and Ahearne et al. (2004) underline the importance of the informational barriers resulting from different national accounting standards and practices. Information costs for outside investors are much higher for companies that lack adequate accounting and governance practices and provide little protection to minority shareholders. La Porta, Lopez-de-Silanes and Shleifer (1999) find that company ownership is more internationally dispersed in countries with good legal protection of minority shareholders. Dahlquist, Pinkowitz and Stulz (2003) show that differences in corporate governance across countries can help explain the home bias: controlling shareholders, who are typically domestic investors, hold a part of the firm's shares such that only a fraction of the issued shares can be freely traded and held by portfolio investors. In the same line, Gelos and Wei (2005) provide strong evidence for a positive relation between both government and corporate transparency and international investments into a particular country; and Giannetti and Simonov (2006) show that the quality of a company's corporate governance not only affects the stocks held in investors' portfolios, but also the probability of new investors buying stocks in a company. Inside investors can extract substantial private benefits from companies with poor corporate governance. Foreign investors typically do not enjoy private benefits in domestic firms, and therefore avoid firms with weak corporate governance 
to minimize expropriation risks.

Stulz (2005) reasons that home bias can be caused by a twin agency problem. On the one hand, there is the agency problem of corporate-insider discretion, meaning that inside investors can extract private benefits and thereby expropriate outside investors. On the other hand, there is the agency problem of state-ruler discretion, meaning that state rulers can expropriate investors by regulations and taxes that are used for the state rulers' own benefit. Stulz shows both empirically and theoretically that share ownership is more concentrated in countries where investor protection is poor and/or the risk of state expropriation is high. The twin agency problem affects international portfolio holdings in three ways: (1) countries with poor governance have a smaller fraction of wealth owned by foreign investors because insiders have a larger ownership share in such countries, (2) smaller countries have a larger fraction of wealth owned by foreign investors, and portfolio investors who live in smaller countries with a smaller share of the world market portfolio invest more abroad, and (3) countries with a high risk of state expropriation have a lower fraction of wealth owned by foreign investors, all else equal. In a similar context, Kho, Stulz and Warnock (2006) show that in countries with weak governance and weak institutions, concentrated ownership is optimal. Consequently, for home bias to disappear in countries with weak public governance, the development of institutions that support decentralized ownership is crucial.

The fifth explanation for home bias, which we discuss next, is based on behavioral finance.

\subsection{Behavioral-based explanations}

All possible explanations for international underdiversification brought forward so far, rely on the traditional research methodology that is based on the assumption of perfectly rational behavior of individuals. However, psychologists and experimental economists have found that in an experimental setting, people tend to suffer from a wishful-thinking bias and self-control problems. They often make judgments using the representativeness heuristic, meaning that when they judge the probability that a model is true, people base their estimate on the degree to which the data resemble the model, rather than making appropriate probability calculations. Since the development of the prospect theory by Kaheman and Tversky (1979) and Tversky and Kahneman (1992), behavioral finance has emerged as an established research area. To explain the home bias in equity portfolios, researches have developed behavioral models where domestic investors consider foreign markets as more risky than they truly are, simply because 
they are foreign. Investors are more familiar with domestic stocks and feel a general sense of discomfort or even fear towards foreign assets (Huberman, 2001). Solnik (2006) uses regret theory to explain international underdiversification: investors use the domestic portfolio as benchmark portfolio and feel the pain of regret when their foreign investments underperform.

Home bias should not only occur when domestic investors have an actual information advantage relative to foreign investors; even the perception of an information advantage relative to foreigners can be sufficient to induce home bias. Indeed, if all investors are provided with the same information, we cannot assume that any particular group of investors has an actual information advantage. But an overconfident investor has a perceived information advantage concerning the investments that he or she is familiar with. Overconfident individuals are known to misjudge their ability in forecasting the performance of familiar assets, and overinvest in the assets they are familiar with (Barber and Odean, 2001, 2002; Karlsson and Nordén, 2007). Kilka and Weber (2000) show in an experimental setting that German investors feel more competent in judging domestic stocks than in judging U.S. stocks. This perceived competence, in turn, seems to have a major influence on peoples' expectations as expressed by the corresponding subjective probability distributions. In particular, Kilka and Weber find that subjective probability distributions of stock returns are on average more dispersed for stocks about which the investor experiences low competence levels (foreign stocks) than for stocks associated with high competence levels (domestic stocks). Furthermore, domestic stocks on average are judged more optimistically than foreign stocks. Dorn and Huberman (2005), in contrast, find no convincing evidence for overconfidence as an explanation for diversification decisions. Based on questionnaire data from Germany from January 1995 to May 2000, they show that both diversification and turnover are mainly driven by the investor's risk attitude: portfolios of risk-averse investors contain twice as many positions as those of risk-tolerant investors.

Morse and Shive (2006) argue that patriotism causes investors to concentrate their stock holdings at home. Using a sample of 53 countries, they find that measures of patriotism are significantly related to home bias measures, even after controlling for capital controls, diversification benefits, information advantages and familiarity.

Studies that focus on the portfolio compositions of individual investors have concluded that the tendency to overinvest in domestic assets is related to specific investor characteristics. Less sophisticated or less experienced investors are more home-biased than sophisticated investors (Grinblatt and Keloharju, 2001; Goetzmann and Kumar, 2004; Karlsson and Nordén, 2007). There is a significantly positive relation between age and diversification and income and di- 
versification (Goetzmann and Kumar, 2004). Karlsson and Nordén (2007) find that men have a tendency to be relatively more home-biased than women. A potential explanation for this finding is that men are more overconfident than women (Barber and Odean, 2001).

A problem with a behavioral-based explanation for home bias is that psychological constructs are difficult to measure and to distinguish. For instance, Grinblatt and Keloharju (2001) find that Finnish investors prefer assets controlled by Finnish-speaking managers. They argue that investors prefer domestic companies because they are more familiar with them. But alternative explanations for their findings are that Finns are simply more patriotic towards Finnish firms, or that domestic investors do have actual information advantages relative to foreigners since they understand the language and local culture better. Unobservable psychological attributes, such as overconfidence, are central to the behavioral approach. They are often proxied by objective investor attributes such as age and gender. However, one can argue whether gender is a good proxy to measure a subjective attribute such as overconfidence. Another way to handle subjective investor attributes is the use of questionnaires or experiments. Two problems can emerge in this case. First, if multiple proxies are proposed to measure the same attribute, it is often the case that individuals' responses are poorly correlated across proxies. Second, questionnaire- or experiment-based studies are difficult to extend to other populations, the proxies used may lose their validity for other populations (Dorn and Huberman, 2005).

Nowadays, the most popular explanations for the equity home bias are information asymmetries, governance issues, and behavioral biases, as the other proposed explanations seem to fail empirically in explaining much of the actual portfolio choices of investors. Researchers are still debating whether rational decision making (information asymmetries) or bounded rationality (behavioral finance) are the right track to follow. Ke, Ng and Wang (2006) try to determine whether the foreign investment decisions of professional money managers are influenced by information asymmetries rather than by investment in the familiar. They find no supporting evidence for the information-based explanation and therefore tend to conclude that the preference for physically proximate investments is driven by psychological familiarity issues. In contrast, Massa and Simonov (2006) argue that familiarity-driven investment decisions are a rational response to information constraints and not a behavioral heuristic. DeMarzo, Kaniel and Kremer (2004) find that the impact of familiarity depends on the degree to which the investor is informed: more informed investors are less affected by familiarity. They conclude that the investment choice is driven by the availability of information, and that familiarity is a substitute for better information. 
Still, a single explanation for home bias in equity portfolios may very well be non-existent. We believe that all explanations discussed in this literature review are valuable. The home bias puzzle is a complex one and a result of a mixture of rational and irrational behavioral of investors, and cross-country institutional differences.

\section{Conclusion}

This paper covers the recent empirical findings and theoretical reasonings for the equity home bias - the fact that people overinvest in domestic stocks. We first show that the intensity of home bias dependens on the way it is measured. We illustrate the degree of international underdiversification for the year 2005, and we show that there has been a modest trend towards more diversification over the last twenty years.

The implicit costs of investing abroad vary significantly depending on the level of development of the home and especially the host country. But also the way these costs are measured matters: a consumption-based approach leads to much lower diversification costs relative to a mean-variance based approach.

Several explanations have been brought forward for the home bias puzzle. The most popular ones are hedging country-specific risks, higher costs for foreign investments, information asymmetries, corporate governance and transparency and behavioral biases. We discuss each of these theories, but we conclude that no single one offers a complete solution to the home bias puzzle. We argue that portfolio decisions of investors are probably driven by a mixture of all explanations brought forward in this paper. This implies that home bias is complex and very hard to model theoretically; and portfolio allocation decisions will probably keep intriguing and inspiring researchers in the future.

\section{References}

[1] Adler, M. and B. Dumas, 1983, International Portfolio Choice and Corporation Finance: A Synthesis, Journal of Finance 38.3, 925-984.

[2] Ahearne, Alan, William Griever, and Francis Warnock, 2004, Information costs and home bias: an analysis of U.S. holdings of foreign equities, Journal of International Economics, $62.2,313-336$. 
[3] Baele, L., C. Pungulescu and J. Ter Horst, 2007, Model uncertainty, financial market intergration and the home bias puzzle, Journal of International Money and Finance 26.4, 606-630.

[4] Barber, B. and T. Odean, 2001, Boys will be boys: gender, overconfidence, and common stock investment, Quarterly Journal of Economics 141, 261-292.

[5] Barber, B. and T. Odean, 2002, Online Investors: Do the Slow Die First, Review of Financial Studies 15.2, 455-487.

[6] Baxter, M., and U. J. Jermann, 1997, The international diversification puzzle is worse than you think, American Economic Review 87, 170-180.

[7] Bekaert, Geert and Campbell R. Harvey, 1997, Emerging equity market volatility, Journal of Financial Economics 43, 29-77.

[8] Berkel, Barbara, 2004, Institutional Determinants of International Equity Portfolios - A Country-Level Analysis, MEA discussion paper 0461, Mannheim Research Institute for the Economics of Aging, University of Mannheim.

[9] Black, Fisher, 1974, International Capital Market Equilibrium with Investment Barriers, Journal of Financial Economics 1.

[10] Bottazzi, L., P. Pesenti and E. van Wincoop, 1996, Wages, Profits, and the International Portfolio Puzzle, European Economic Review 40, 219-254.

[11] Brealey, R.A., I.A. Cooper and E. Kaplanis, 1999, What is the International Dimension of International Finance?, European Finance Review 3, 103-119.

[12] Brennan, M.J. and H.H. Cao, 1997, International Portfolio Investment Flows, Journal of Finance 52.5, 1851-1880.

[13] Brennan, M.J., H.H. Cao, N. Strong and X. Xu, 2005, The dynamics of international equity market expectations, Journal of Financial Economics 77, 257-288.

[14] Campbell John Y. and John H. Cochrane, 2000, Explaining the Poor Performance of Consumption-based Asset Pricing Models, Journal of Finance 55.6, 28632878.

[15] Chan, Kalok, Vicentiu Covrig, and Lilian Ng, 2005, What Determines the Domestic Bias and Foreign Bias? Evidence from Mutual Fund Equity Allocations Worldwide, Journal of Finance 60.3, 1495-1534. 
[16] Chen, K., Z., Chen and K. Wei, 2003, Disclosure, corporate governance, and the cost of equity capital: evidence from Asia's emerging markets, Working Paper, Hong Kong University of Science and Technology.

[17] Choe, H., B.C. Kho and R.M. Stulz, 2005, Do domestic investors have an edge? The trading experience of foreign investors in Korea, Review of Financial Studies 18.3, 795829 .

[18] Chue, Timothy K., 2007, Is Equity Home Bias Really Suboptimal?, AFA 2007 Chicago Meetings Paper Available at SSRN: http://ssrn.com/abstract $=887280$

[19] Cochrane, John, H., 1996, A Cross-Sectional Test of an Investment-Based Asset Pricing Model, Journal of Political Economy 104, 572-621.

[20] Cole, H. and M. Obstfeld, 1991, Commodity trade and international risk sharing: How much do financial markets matter? Journal of Monetary Economics 28, 3-24.

[21] Cooper, Ian A. and Evi Kaplanis, 1994, Home Bias in Equity Portfolios, Inflation Hedging, and International Capital Market Equilibrium, Review of Financial Studies 7.1, 45-60.

[22] Cooper, Ian A. and Evi Kaplanis, 2000, Partially segmented international capital markets and international capital budgeting, Journal of International Money and Finance 19, 309-329.

[23] Coval, J.D. and T. Moskowitz, 1999, Home bias at home: Local equity preference in domestic portfolios, Journal of Finance 54.6, 2045-2073.

[24] Coval, J.D. and T. Moskowitz, 2001, The geography of investment: informed trading and asset pricing, Journal of Political Economy 109.4, 811-841.

[25] Dahlquist, Marcus, Lee Pinkowitz, Rene Stulz and Rohan Williamson, 2003, Corporate Governance and The Home Bias, Journal of Financial and Quantitative Analysis, 38.1, $87-110$.

[26] DeMarzo, P., R. Kaniel, and I. Kremer, 2004, Diversification as a Public Good: Community Effects in Portfolio Choice, Journal of Finance 59.4, 1677-1716.

[27] De Moor, L. and P. Sercu, 2004, CAPM tests and alternative factor portfolio composition: getting the alpha's right, Tijdschrift voor Economie en Management, 49.4 (Nov.), 789 846. 
[28] Dorn, D. and G. Huberman, 2005, Talk and Action: What Individual Investors Say and What They Do, Review of Finance 9.5, 437-481

[29] Dvorak, T., 2005, Do Domestic Investors Have an Information Advantage? Evidence from Indonesia, Journal of Finance 60.2, 817-839.

[30] Easton, Peter, 2004, PE rations and PEG ratios, and estimating the implied expected rate of return on equity capital, The Accounting Review 80, 501-538.

[31] Elton, Edwin, J., 1999, Expected Return, ,Realized Return, and Asset Pricing Tests, Journal of Finance 54.4, 1199-1220.

[32] Epstein, Larry. G. and S.E. Zin, 1989, Substitution, Risk-Aversion, and the Temporal Behavior of Consumption and Asset Returns: A Theoretical Framework, Econometrica 57, 937-969.

[33] Errunza, Vihang and Etienne Losq, 1985, International asset pricing and mild segmentation: Theory and test, Journal of Finance 40, 105-124.

[34] Errunza, Vihang, K. Hogan and M-W Hung, 1999, Can the Gains from International Diversification Be Achieved without Trading Abroad?, Journal of Finance 54.6, 20752107.

[35] Faruqee, H., S. Li and I.K. Yan, 2004, The Determinants of International Portfolio Holdings and Home Bias, IMF Working Paper, WP/04/34.

[36] Ferson, W.E. and C.R. Harvey, 1994, Sources of Risk and Expected Returns in Global Equity Markets, Journal of Banking \& Finance 18.4, 775-803.

[37] Fidora, M., M. Fratzscher and C. Thimann, 2007, Home bias in global bond and equity markets: the role of real exchange rate volatility, Journal of International Money and Finance 26.4, 222-225.

[38] French, K. and J. Poterba, 1990, Japanese and U.S. cross-border common stock investments, Journal of the Japanese and International Economics 4, 476-493.

[39] French, K. and J. Poterba, 1991, Investor diversification and international equity markets, American Economic Review 81, 222-226. 
[40] Froot, K.A. and K. Rogoff, 1995, Perspectives on PPP and Long-Run Real Exchange Rates, in Handbook of international Economics 3, G. Grossman and K. Rogoff, eds. Amsterdam, Elsevier-North Holland.

[41] Garlappi, L., R. Uppal and T. Wang, 2007, Portfolio selection with parameter and model uncertainty: A multi-prior approach, Review of Financial Studies 20.1, 41-81.

[42] Gelos R.G. and S-J Wei, 2002, Transparency and International Investor Behavior, NBER Working Paper No. 9260, 136.

[43] Gelos R.G., and S-J Wei, 2005, Transparency and International Portfolio Holdings, Journal of Finance 60.6, 2987-3020.

[44] Giannetti, M. and A. Simonov, 2006, Which Investors Fear Expropriation? Evidence from Investors' Portfolio Choices, Journal of Finance 61.3, 1507-1547.

[45] Glassman, Debra A. and Leigh A. Riddick, 1994, International diversification: new evidence of market segmentation, Scandinavian Journal of Economics 95.1, 97-109.

[46] Glassman, Debra A. and Leigh A. Riddick, 2001, What causes home asset bias and how should it be measured?, Journal of Empirical Finance 8, 35-54.

[47] Goetzmann, W.N. and A. Kumar, 2004, Diversification Decisions of Individual Investors and Asset Prices, Yale ICF Working Paper No. 03-31. Available at SSRN: http://ssrn.com/abstract $=469441$.

[48] Gordon Stephen and Lucie Samson, 2002, Comparing Consumption-Based Asset-Pricing Models, The Canadian Journal of Economics 35.3, 586-610.

[49] Grinblatt, M. and M. Keloharju, 2000, The investment behavior and performance of various investor types: A study of Finland's unique data set, Journal of Financial Economics $55.1,43-67$.

[50] Grinblatt, M. and M. Keloharju, 2001, How distance, language, and culture influence stock holdings and trades, Journal of Finance 56, 1053-1073.

[51] Grote, M.H. and M.P. Umber, 2006, Home biased? A spatial analysis of the domestic merging behavior of US firms, Working Paper 161, Goethe University Frankfurt am Main.

[52] Hau, H., 2001, Location matters: An examination of trading profits, Journal of Finance $56.5,1959-1983$. 
[53] Huang, R.D. and C-Y Shiu, 2006, Local effects of foreign ownership in an emerging financial market: Evidence from qualified foreign institutional investors in Taiwan, presented on EFMA 2007 Annual Conference, June 27-30, Vienna.

[54] Huberman, G., 2001, Familiarity Breeds Investment, Review of Financial Studies 14, 659680.

[55] Jeske, K., 2001, Equity home bias - can information cost explain the puzzle?, Federal Reserve Bank of Atlanta, Economic Review 2001, Q3, 31-42.

[56] Julliard, C., 2003, The International Diversification Puzzle is Not Worse Than You Think, International Finance working paper 0301004, EconWPA.

[57] Kahneman, D. and A. Tversky, 1979, Prospect Theory: An Analysis of Decision Under Risk, Econometrica 47, 263-291.

[58] Karlsson, A. and L. Nordén, 2007, Home sweet home: Home bias and international diversification among individual investors, Journal of Banking $\mathcal{E}$ Finance 31.2, 317-333.

[59] Karolyi, Andrew and Rene M. Stulz, 2003, Are Financial Assets Priced Locally or Globally?, in the Handbook of the Economics of Finance, G. Constantinides, M. Harris, and R.M. Stulz, eds. Elsevier North Holland, 2003.

[60] Ke, D., L. Ng, and Q. Wang, 2006, Home Bias in Foreign Investment Decisions, EFA 2006 Zurich Meetings Available at SSRN: http://ssrn.com/abstract=891383.

[61] Kho, Bong Chan, Rene M. Stulz and Francis E. Warnock, 2006, Financial globalization, governance and the evolution of the home bias, BIS Working Papers 220.

[62] Kilka, M. and M. Weber, 2000, Home Bias in International Stock Return Expectation, Journal og Psychology and Financial Markets 1, 176-192.

[63] Lane, Philip and G.M. Milesi-Ferretti, 2001, The External Wealth of Nations: Measures of Foreign Assets and Liabilities for Industrial and Developing Countries, Journal of International Economics 55.2, 263-294.

[64] Lane, Philip and G.M. Milesi-Ferretti, 2004, International Investment Patterns, IMF Working Paper 04/134.

[65] Lane, Philip and Gian M. Milesi-Ferretti, 2005, The International Equity Holdings of Euro Area Investors, IIIS Discussion Paper 104. 
[66] La Porta, Rafael, F. Lopez-de-Silanes, and A. Shleifer, 1999, Corporate ownership around the world, Journal of Finance 58, 471-517.

[67] Lau, Sie Ting, Lilian Ng and Bohui Zhang, 2007, The World Price of Home Bias, paper presented at the Asian Finance Association Conference, Hong Kong, July 2007.

[68] Lewis, Karen K., 1996, Consumption, Stock Returns, and the Gains From International Risk-Sharing, NBER Working Paper 5410.

[69] Lewis, Karen K., 1999, Trying to Explain Home Bias in Equities and Consumption, Journal of Economic Literature 37, 571-608.

[70] Lewis, Karen K., 2000, Why do stocks and consumption imply such different gains from international risk sharing?, Journal of International Economics 52, 1-35.

[71] Markowitz, H. M, 1952, Portfolio selection, Journal of Finance 7, 7791.

[72] Martin, P. and H. Rey, 2004, Financial super-markets: size matters for asset trade, Journal of International Economics 64, 335-361.

[73] Massa, M. and A. Simonov, 2006, Hedging, Familiarity and Portfolio Choice, Review of Financial Studies 19.2, 633-685.

[74] Merton, R. C., 1980, On estimating the expected return on the market, Journal of Financial Economics8, 323361.

[75] Morse, Adair and Shive, Sophie, 2006, Patriotism in Your Portfolio, Available at SSRN: http://ssrn.com/abstract $=406200$.

[76] Obstfeld, Maurice and Kenneth Rogoff, 1998, Foundations of International Macroeconomics (MIT Press, Cambridge, MA).

[77] Pagano, M, O. Randl, A.A. Roell, and J. Zechner, 2001, What makes stock exchanges succeed? Evidence from cross-listing decisions, European Economic Review 45.4-6, 770782.

[78] Pástor, L., 2000, Portfolio Selection and Asset Pricing Models, Journal of Finance 55.1, 179-223.

[79] Pástor, Lubos, Meenakshi Sinha, and Bhaskaran Swaminathan, 2006, Estimating the Intertemporal Risk-Return Tradeoff Using the Implied Cost of Capital, NBER Working Paper 11941. 
[80] Portes, R. and H. Rey, 2005, The determinants of cross-border equity flows, Journal of International Economics 65.2, 269-296.

[81] Sarkissian, M. and Michael J. Schill, 2004, The Overseas Listing Decision: New Evidence of Proximity Preference, Review of Financial Studies 17, 769-809.

[82] Sercu, Piet, 1980, A Generalization of the International Asset Pricing Model, Revue de l'Association Française de Finance 1.1, 91-135.

[83] Sercu, Piet and Rosanne Vanpée, 2007a, Estimating the Costs of International Equity Investments, Forthcoming.

[84] Sercu, Piet and Rosanne Vanpée, 2007b, The Plausibility of Risk Estimates and Implied Costs to International Equity Investments, Forthcoming.

[85] Sharpe, William, 1963, A simplified model for portfolio analysis, Management Science 9, 277293.

[86] Solnik, Bruno, 1996, International Investments. 3rd edn. Addison-Wesley Publishing, Reading, MA.

[87] Solnik, Bruno, 2006, Home Bias and Regret: An International Equilibrium Model, Available at SSRN: http://ssrn.com/abstract $=828405$.

[88] Stockman, Alan C. and Harris Dellas, 1989, International portfolio nondiversification and exchange rate variability, Journal of International Economics 26, 271-290.

[89] Stulz, Rene, M., 1981, On the effects of barriers to international investment, Journal of Finance 36.4, 923-934.

[90] Stulz, Rene, M., 1999, Globalization of equity markets and the cost of capital, Working Papr, Dice Center, Ohio State University.

[91] Stulz, Rene, M., 2005, The Limits of Financial Globalization, Journal of Finance 60.4, 1595-1638.

[92] Tesar, L., 1993, International risk-sharing and nontraded goods, Journal of International Economics 35.1-2, 69-89.

[93] Tesar, L. and I. Werner, 1995, Home bias and high turnover, Journal of International Money and Finance 14, 467-492. 
[94] Tversky, A. and D. Kahneman, 1992, Advances in Prospect Theory: Cumulative Representation of Uncertainty, Journal of Risk and Uncertainty 5, 297-323.

[95] Van Nieuwerburgh S. and L. Veldkamp, 2007, Information Immobility and the Home Bias Puzzle, AFA 2006 Boston Meetings Paper Available at SSRN: http://ssrn.com/abstract $=619363$.

[96] van Wincoop, E., 1994, Welfare gains from international risk sharing, Journal of Monetary Economics 34, 175-200.

[97] van Wincoop, E., 1999, How big are potential welfare gains from international risksharing?, Journal of International Economics 47.1, 109-135.

[98] Warnock, Francis, 2001, Home bias and high turnover reconsidered, Journal of International Money and Finance 21.6, 795-805.

[99] Weil, Philippe, 1990, Nonexpected Utility in Macroeconomics, Quarterly Journal of Economics 105.1, 29-42.

[100] Wheatley, Simon M., 2001, Keeping up with the Joneses, human capital and the homeequity biases, Working Paper, University of Melbourne. 